\title{
Environmental Protection and Investment Arbitration: Yin and Yang?*
}

Fecha de recepción: 3 de marzo de 2016

Fecha de aceptación: 1 de junio de 2016

Doi: 10.12804/revistas.urosario.edu.co/acdi/a.5296

\section{Laurence Boisson de Chazournes*}

Abstract: This article explores the interactions between international environmental law and international investment law. It discusses existing tools and procedural devices available before international courts and tribunals to promote compliance with emerging principles, standards, and commitments relating to sustainability. This article first considers the way in which international courts and tribunals have had recourse to environmental protection through treaty interpretation. It then appraises the various ways that environmental protection is referred to in bilateral investment treaties. Finally, the article explores the procedural devices that could be used to take into account / address environmental considerations within the investment framework.

Key words: Environmental protection, State's regulatory power, exceptions, treaty interpretation BIT substantive standards, corporate social responsibility, environmental impact assessment, experts.

* This article is drawn from a presentation made during the IBA Conference jointly organized with the International Chamber of Commerce (ICC) and the Permanent Court of Arbitration (PCA): COP21 - Climate Change Related Disputes: A Role for International Arbitration and $A D R$, held in Paris on 7 December 2015.

** Professor of International Law and International Organization at the University of Geneva; Associate Member of the Institut de droit international; Arbitrator and Counsel with various International Courts and Tribunals. Correo electrónico: Laurence. BoissonDeChazournes@unige.ch

Para citar este artículo: Boisson de Chazournes, L., "Environmental protection and investment arbitration: yin and yang?", Anuario Colombiano de Derecbo Internacional (ACDI), 2017, 10, pp. 371-399. Doi: 10.12804/ revistas.urosario.edu.co/acdi/a.5296 
Protección del medio ambiente y arbitraje de inversión: ¿yin y yang?

Resumen: este documento analiza las relaciones entre el derecho internacional del medio ambiente y el derecho internacional de inversión. Así mismo, discute las herramientas existentes y los mecanismos procesales disponibles ante las cortes y los tribunales internacionales para promover el cumplimiento de los principios emergentes, las normas y los compromisos relacionados con la sostenibilidad. Este artículo considera la forma en que las cortes y los tribunales internacionales han recurrido a la protección del medio ambiente mediante la interpretación de tratados. También, evalúa las diferentes formas a que hace referencia la protección del medio ambiente en tratados de inversión bilateral. Finalmente, el texto examina los dispositivos procesales que podrían ser usados para tener en cuenta y tratar las consideraciones medioambientales dentro del marco de referencia de la inversión.

Palabras clave: protección del medio ambiente, poder regulador del Estado, excepciones, Tratado de Interpretación Bilateral (TBI) estándar, responsabilidad social corporativa, evaluación del impacto ambiental, expertos.

Proteção do Meio Ambiente e arbitragem de investimento: ¿Yin e yang?

Resumo: Este documento analisa as relações entre o Direito Internacional do Meio Ambiente e o Direito Internacional de Investimento. Igualmente, discute as ferramentas existentes e os mecanismos processais disponíveis ante as cortes e os tribunais internacionais para promover o cumprimento dos princípios emergentes, as normas e os compromissos relacionados com a sustentabilidade. Este artigo considera a forma em que as cortes e os tribunais internacionais têm recorrido à proteção do meio ambiente por meio da interpretação de tratados. Também, avalia as diferentes formas a que faz referência a proteção do meio ambiente em Tratados de Investimento Bilateral. Finalmente, o documento examina os dispositivos processais que poderiam ser usados para ter em conta e tratar as considerações meio ambientais dentro do marco de referência do investimento. 
Palavras-chave: Proteção do meio ambiente, poder regulador do Estado, exceções, Tratado de Interpretação Bilateral TBI standard, Responsabilidade Social Corporativa, avaliação do impacto ambiental, expertos.

\section{Introduction}

Environmental protection can be wide-ranging and touch upon many different issues. The award in the arbitration regarding the Iron Rbine Railway noted that: " $[\ldots]$ 'environment' is broadly referred to as including air, water, land, flora and fauna, natural ecosystems and sites, human health and safety, and climate. The emerging principles, whatever their current status, make reference to conservation, management, notions of prevention and of sustainable development, and protection for future generations". ${ }^{1}$

Over the past four decades, there has been a proliferation of legal instruments relating to the environment. Environmental protection includes not only compensation measures for damage caused, but also, and more significantly, preventive tools and solutions. In the meantime, the promotion and globalization of economic activities, through trade and/ or investments, has become a key driver of economic development in a number of countries.

This explains why we may observe an interaction between international environmental law and international trade or investment law. Given that these different bodies of norms increasingly interact with one another, courts and tribunals are required to apprehend and scrutinize this growing synergy. It presents new challenges in treaty interpretation and implementation.

This article first considers the way in which international courts and tribunals have had recourse to environmental protection through treaty interpretation. It then appraises the various ways that environmental protection is referred to in bilateral investment treaties. Finally, the article explores the procedural devices that could be used to take environmental considerations into account within the investment framework.

\footnotetext{
1 Award in the Arbitration Regarding the Iron Rhine Railway (Kingdom of Belgium/Kingdom of the Netherlands), Award, 24 May 2005, Report of international Arbitral Awards, Vol XXVII pp. 35-125, para. 58.
} 


\title{
I. International Courts and Tribunals and the Protection of the Environment
}

\begin{abstract}
Absent specific provisions applicable to the environment in a treaty or if there is a need to broaden the scope of existing provisions, courts and tribunals may have recourse to canons of interpretation as codified in the 1969 Vienna Convention on the Law of Treaties in an attempt to reconcile environmental protection with other issues. When interpreting a treaty, courts and tribunals give priority to the terms of the treaty, taking into consideration the following aids to interpretation: inter alia, context, object and purpose, subsequent agreements and State practice, any applicable rule of international law in force between the parties, as well as the travaux preparatoires and the circumstances surrounding a treaty's adoption as subsidiary means of interpretation. ${ }^{2}$ These aids have allowed environmental considerations to be addressed in various types of treaties.
\end{abstract}

\section{A. Preambular Provisions: Their Contribution to Integrating Environmental Concerns}

Preambular provisions help to identify the object and purpose of a treaty. One particularly notable example of a preambular provision used to guide the interpretation of a substantive provision from an environmental standpoint was in the WTO Appellate Body's (AB) decision in U.S. - Shrimp. ${ }^{3}$ In its report, the $\mathrm{AB}$ sought to interpret the term "exhaustible natural resources" under Article XX (g) GATT and said:

The words of Article XX (g), 'exhaustible natural resources', were actually crafted more than 50 years ago. They must be read by a treaty interpreter in the light of contemporary concerns of the community of nations about the protection and conservation of the environment. While Article XX was not modified in the Uruguay Round, the preamble attached to the WTO Agreement shows that the signatories to that

\footnotetext{
2 Article 31(3), Vienna Convention on the Law of Treaties 1969 (155 UNTS 331). See also, Boisson de Chazournes, L., "Rules of Interpretation and Investment Arbitration" in Meg Kinnear et al. (Eds)., Building International Investment Law: The First 50 Years of ICSID (Kluwer Law International, 2015).

3 United States - Import Probibition of Certain Shrimp and Sbrimp Products WT/DS58/AB/R (1998).
} 
Agreement were, in 1994, fully aware of the importance and legitimacy of environmental protection as a goal of national and international policy. The preamble of the WTO Agreement — which informs not only the GATT 1994, but also the other covered agreements - explicitly acknowledges 'the objective of sustainable development'.

This is an approach that could be followed by investment arbitration tribunals to address the tension between evolving environmental considerations and optimal investment protection requiring consistency and stability. Indeed, under Article 31 of the Vienna Convention on the Law of Treaties, the object and purpose of a treaty is a key element of interpretation. The preamble to a treaty is often instructive for the determination of its object and purpose. As the WTO AB put it in U.S. - Shrimp: " [...] the specific language of the preamble to the WTO Agreement [...] gives color, texture and shading to the rights and obligations of Members under the WTO Agreement, generally, and under the GATT 1994, in particular". 5

\section{B. Interpretation of Substantive Provisions}

Environmental norms and standards have also been taken into account by international courts and tribunals in the interpretation of substantive provisions. On various occasions, the International Court of Justice (ICJ), applying the customary canons of interpretation, has stated that existing environmental norms and standards should be taken into account when interpreting a treaty: "To evaluate the environmental risks, current standards must be taken into consideration". ${ }^{6}$ These standards were considered in a comprehensive manner in the Gabčíkovo-Nagymaros case. For the Court in that case, these standards included the principles of prevention and precaution, intergenerational equity and sustainable development.

The ICJ sought to find a new way to balance different interests and underlined the importance of environmental standards in this balancing exercise. The balancing exercise is evident in the following paragraph which discusses the concept of sustainable development:

$4 \quad$ Ibid., para. 129.

5 United States - Import Probibition of Certain Shrimp and Shrimp Products WT/DS58/AB/R (1998), para. 155.

6 Case Concerning the Gabčkovo-Nagymaros Project (Hungary/Slovakia), ICJ Reports 1997 p. 7. 
Throughout the ages, mankind has, for economic and other reasons, constantly interfered with nature. In the past, this was often done without consideration of the effects upon the environment. Owing to new scientific insights and to a growing awareness of the risks for mankind - for present and future generations - of pursuit of such interventions at an unconsidered and unabated pace, new norms and standards have been developed, set forth in a great number of instruments during the last two decades. Such new norms have to be taken into consideration, and such new standards given proper weight, not only when States contemplate new activities but also when continuing with activities begun in the past. This need to reconcile economic development with protection of the environment is aptly expressed in the concept of sustainable development. ${ }^{7}$

While the Court never abandoned the treaty that had been agreed by the parties in place of newly developed norms and standards of environmental protection, it nevertheless sought to interpret the 1977 treaty related to the Gabčíkovo-Nagymaros project in light of those new norms and standards. Indeed, the Court clarified that individual treaties are not to be interpreted in isolation but rather in the context of evolving international law. The development of the international legal regime over time can have a bearing on the interpretation and application of existing treaties and thus the parties are called upon to take these developments into account. It said: "The Court does not consider that new developments in the state of environmental knowledge and of environmental law can be said to have been completely unforeseen. What is more, the formulation of Articles 15, 19 and 20, designed to accommodate change, made it possible for the parties to take account of such developments and to apply them when implementing those treaty provisions". ${ }^{8}$

Moreover, it was underlined that "the Treaty is not static, and is open to adapt to emerging norms of international law". "This evolutive interpretation subsequently found favor with the Tribunal in the Iron Rhine Arbitration. There, drawing support from the ICJ's approach in GabrikovoNagymaros, it was affirmed that: "An evolutive interpretation, which would

\footnotetext{
$7 \quad$ Ibid., para. 140.

$8 \quad$ Ibid., para. 104.

$9 \quad$ Ibid., para. 112.
} 
ensure an application of the treaty that would be effective in terms of its object and purpose, will be preferred to a strict application of the intertemporal rule". ${ }^{10}$

The Tribunal cited Article 31(3) (c) of the Vienna Convention on the Law of Treaties as the legal basis for a contemporaneous interpretation of the treaties at issue. ${ }^{11}$ The Tribunal therefore considered principles of international environmental law in their current form at the date of its decision as relevant to its decision. ${ }^{12}$

The Tribunal in the Indus Waters Kishenganga Arbitration followed the same pattern of reasoning as the ICJ and the Iron Rhine Tribunal. It said:

It is established that principles of international environmental law must be taken into account even when (unlike the present case) interpreting treaties concluded before the development of that body of law. The Iron Rhine Tribunal applied concepts of customary international environmental law to treaties dating back to the mid-nineteenth century, when principles of environmental protection were rarely if ever considered in international agreements and did not form any part of customary international law. Similarly, the International Court of Justice in Gabcikovo-Nagymaros ruled that, whenever necessary for the application of a treaty, "new norms have to be taken into consideration, and $[\ldots]$ new standards given proper weight". It is therefore incumbent upon this Court to interpret and apply this 1960 Treaty in light of the customary international principles for the protection of the environment in force today. ${ }^{13}$

\footnotetext{
10 Award in the Arbitration Regarding the Iron Rbine Railway (Kingdom of Belgium/Kingdom of the Netherlands), 24 May 2005, Reports of International Arbitral Awards, Vol. XXVII pp. 35125, para. 80.

11 According to this provision "any relevant rules of international law applicable in the relations between the Parties" shall be taken into account in interpreting international agreements.

12 Award in the Arbitration Regarding the Iron Rbine Railway (Kingdom of Belgium/Kingdom of the Netherlands), 24 May 2005, Reports of International Arbitral Awards, Vol. XXVII pp. 35125, para. 58.

13 Indus Waters Kishenganga Arbitration (Pakistan v. India), Partial Award (PCA 2013), para. 452 (original footnotes omitted).
} 
It also discussed the interpretation of substantive provisions in accordance with international law in the following way:

As the Court noted with approval in its Partial Award, the Tribunal in the Iron Rhine Arbitration, building on the judgment of the International Court of Justice in the Case concerning the Gabcíkovo-Nagymaros Project, held that principles of international environmental law must be taken into account even when interpreting treaties concluded before the development of that body of law. In implementing this holding, the Court notes that the place of customary international law in the interpretation or application of the Indus Waters Treaty remains subject to Paragraph 29. ${ }^{14}$

Notably, the ICJ had also suggested in the Gabrikovo-Nagymaros case that no explicit treaty provision was required to apply new environmental norms. ${ }^{15}$ This has been commended as a sensible approach given that where treaties do not provide for obligations under customary international law — such as environmental impact assessments — the latter should in any event apply. ${ }^{16}$ This interpretative approach has been followed in subsequent cases, such as in the Pulp Mills on the River Uruguay case, in which the Court interpreted the 1975 Statute of the River Uruguay, at issue in that case, as follows:

The Court next briefly turns to the issue of how the 1975 Statute is to be interpreted. [...] In interpreting the terms of the 1975 Statute, the Court will have recourse to the customary rules on treaty interpretation as reflected in Article 31 of the Vienna Convention. Accordingly, the 1975 Statute is to be "interpreted in good faith in accordance with the ordinary meaning to be given to the terms of the [Statute] in their context and in light of its object and purpose". That interpretation will also take into account, together with the context, "any relevant rules of international law applicable in the relations between the parties. ${ }^{17}$

\footnotetext{
14 Ibid., para. 111.

15 Case Concerning the Gabcíkovo-Nagymaros Project (Hungary/Slovakia), ICJ Reports 1997 p. 7, para. 140 .

16 Boyle, A., "Gabćíkovo-Nagymaros Case: New Law in Old Bottles" 8 (1997) Yearbook of International Environmental Law 13-20, p. 15.

17 Case Concerning Pulp Mills on the River Uruguay (Argentina v. Uruguay), ICJ Reports 2010 p. 14, para. 65.
} 
For the Court, those relevant rules encompassed both rules of general international law and rules contained in multilateral conventions to which the two States were parties. ${ }^{18}$ Among the principles of general international law to be taken into account is the general obligation for States not to conduct activities that would be detrimental to the environment beyond their jurisdiction, as was recognized by the International Court of Justice in Legality of the Threat or Use of Nuclear Weapons. ${ }^{19}$

\section{General Exceptions and Environmental Protection}

General exceptions, such as those under Article XX of the GATT 1994, afford States regulatory space to achieve certain policy objectives. In U.S. - Gasoline, the Appellate Body of the WTO held that clean air could be an exhaustible natural resource within the remit of GATT Article XX, and thus the USA was justified in adopting a measure that imposed stricter environmental criteria on imported fuel. ${ }^{20}$ In U.S. - Tuna II, the WTO's Appellate Body confirmed that a Member could adopt trade restrictive measures that had as their objective environmental protection. ${ }^{21}$ However, these measures must be exercised in accordance with certain requirements, namely that they not be more trade-restrictive than necessary to fulfil a legitimate objective.

In U.S. - Shrimp the AB sought to clarify those conditions:

What we have decided in this appeal is simply this: although the measure of the United States in dispute in this appeal serves an environmental objective that is recognized as legitimate under paragraph (g) of Article XX of the GATT 1994, this measure has been applied by the United States in a manner which constitutes arbitrary and unjustifiable discrimination between Members of the WTO, contrary to the requirements of the chapeau of Article XX. For all of the specific reasons outlined in this Report, this measure does not qualify for the exemption that

\footnotetext{
18 Ibid., para. 66.

19 Legality of the Threat or Use of Nuclear Weapons, Advisory Opinion, ICJ Reports $1996 \mathrm{p}$. 226, pp. 241-242, para. 29.

20 United States - Standards for Reformulated and Conventional Gasoline, WT/DS2 (1996).

21 United States - Measures Concerning the Importation, Marketing and Sale of Tuna and Tuna Products, WT/DS381/AB (2012).
} 
Article XX of the GATT 1994 affords to measures which serve certain recognized, legitimate environmental purposes but which, at the same time, are not applied in a manner that constitutes a means of arbitrary or unjustifiable discrimination between countries where the same conditions prevail or a disguised restriction on international trade. As we emphasized in United States - Gasoline, WTO Members are free to adopt their own policies aimed at protecting the environment as long as, in so doing, they fulfil their obligations and respect the rights of other Members under the WTO Agreement. ${ }^{22}$

Reference to other courts and tribunals' case law is instructive as it highlights that, in practice, methods of interpretation may serve the purpose of reconciling environmental considerations with other international obligations. Such reconciliation is also emerging in the context of investment disputes. Investment arbitral tribunals may draw inspiration from the case law of other courts and tribunals in this respect.

\section{Bilateral Investment Treaties and the Protection of the Environment}

At first glance, bilateral investment treaties (BITs) are not appropriate instruments for the provision of environmental obligations because their primary purpose is the protection of investments. Increasingly, however, provisions of this kind are present in such treaties. These can be classified in three categories. First, preambular provisions often refer to environmental protection in general terms as an objective. Second, by way of exception or derogatory language, environmental concerns may be part and parcel of the State's regulatory power. Third, environmental obligations may be incorporated with provisions on corporate social responsibility and the obligation to conduct an environmental impact assessment. Each of these aspects, which will be examined in turn, influences the protection of investments.

\section{A. Preambular Provisions}

Investment treaties can help facilitate environmental protection. A nonexhaustive survey of BIT preambles confirms this observation. As said,

22 United States - Import Probibition of Certain Shrimp and Shrimp Products WT/DS58/AB/R (1998), paras. 185-186. 
preambular provisions are indicative of the "object and purpose" of a treaty. References to environmental protection or to sustainable development have found their place in BIT preambles, together with provisions containing other objectives, such as the promotion of investment. The following extracts are illustrative of this trend:

\section{BIT United States-Rwanda}

[...] Recognizing that agreement on the treatment to be accorded such investment will stimulate the flow of private capital and the economic development of the Parties;

[...] Desiring to achieve these objectives in a manner consistent with the protection of health, safety, and the environment, and the promotion of internationally recognized labor rights. ${ }^{23}$

\section{BIT Canada-Benin}

Recognizing that the promotion and the protection of investments of investors of one Contracting Party in the territory of the other Contracting Party are conducive to the stimulation of mutually beneficial economic activity, the development of economic cooperation between both countries and the promotion of sustainable development. ${ }^{24}$

\section{BIT China-Canada}

Recognizing the need to promote investment based on the principles of sustainable development. ${ }^{25}$

\footnotetext{
23 Treaty between the Government of the United States of America and the Government of the Republic of Rwanda Concerning the Encouragement and Reciprocal Protection of Investment, 19 February 2008, available at: http://go.usa.gov/3pmXd, consulted on 14 February 2016.

24 Agreement Between the Government of Canada and the Government of the Republic of Benin for the Promotion and Reciprocal Protection of Investments, 9 January 2013, available at: http://investmentpolicyhub.unctad.org/IIA/country/35/treaty/563, consulted on 14 February 2016.

25 Agreement Between the Government of Canada and the Government of the People's Republic of China for the Promotion and Reciprocal Protection of Investments, 9 September 2012, http://investmentpolicyhub.unctad.org/IIA/country/42/treaty/778, consulted on 14 February 2016.
} 


\section{BIT Brazil-Mozambique}

Acknowledging the essential role of investment in the promotion of sustainable development, economic growth, poverty reduction, job creation, expansion of productive capacity and human development. ${ }^{26}$

The insertion of similar language in the preambles of recent model BITs also evidences this trend. ${ }^{27}$ Those preambular clauses will help inform the interpretation to be given to rights and obligations contained in a treaty.

\section{B. Regulatory Power and Exceptions}

BIT provisions can explicitly acknowledge that the promotion and protection of investment may not result in relaxing environmental standards. The following extracts are examples of such provisions:

\section{BIT Switzerland-Mexico}

The Parties recognize that it is inappropriate to encourage investment by relaxing domestic health, safety or environmental measures. Accordingly, neither Party should waive or otherwise derogate from, or offer to waive or derogate, such measures as an encouragement for the establishment, acquisition, expansion or retention in its territory of an investment of an investor. If either Party considers that the other Party has offered such an encouragement, it may request consultations. ${ }^{28}$

\footnotetext{
26 Acordo de cooperacão e facilitacão de investimentos entre o governo da república federativa do Brasil e o governo da república de Moçambique, 2015, available at: http:// investmentpolicyhub.unctad.org/Download/TreatyFile/3352, consulted on 15 February 2016.

27 UnCTAD Investment Policy Framework for Sustainable Development, Principles for Investment Policy Making (2015), available at http://unctad.org/en/PublicationsLibrary/ diaepcb2015d5_en.pdf, consulted on 15 February 2016; Agreement between the Kingdom of Norway and [...] for the Promotion and Protection of Investments, Draft Version, 13 May 2015, available at http://investmentpolicyhub.unctad.org/Download/TreatyFile/2873, consulted on 15 February 2016; Model text for the Indian Bilateral Investment Treaty available at http://finmin.nic.in/the_ministry/dept_eco_affairs/investment_division/ ModelBIT_Annex.pdf, consulted on 16 February 2016.

28 Ad Article 3 of the Protocol of the Agreement between the Swiss Confederation and the United Mexican States on the Promotion and Reciprocal Protection of Investments,
} 


\section{BIT Belgium-Luxembourg Economic Union- Mozambique}

1. Recognizing the right of each Contracting Party to establish its own levels of domestic environmental protection and environmental development policies and priorities, and to adopt or modify accordingly its environmental laws, each Contracting Party shall strive to continue to improve those laws [...].

3. The Contracting Parties reaffirm their commitments under the international environmental agreements, which they have accepted. They shall strive to ensure that such commitments are fully recognised and implemented by their domestic laws. ${ }^{29}$

Those provisions are aimed at preserving a certain amount of policy space for States and set up a framework in which a State can exercise its regulatory power without compromising the purpose of a treaty. It may be that this power is in tension with other provisions designed to protect the investor. Those include, inter alia, fair and equitable treatment (FET) and the regulatory framework of expropriation. There is a general consensus around the idea that the application of FET "is crucially dependent on an evaluation of the facts of each case". 30 The test of whether the investor's expectations are fair is an objective one. As said in the El Paso award, "these expectations, as well as their violation, have to be examined objectively $[. .$.$] legitimate expectations cannot be solely the subjective$ expectations of the investor, but have to correspond to the objective expectations than [sic] can be deduced from the circumstances and with due regard to the rights of the State". ${ }^{31}$

10 July 1995, available at http://investmentpolicyhub.unctad.org/Download/TreatyFile/2006, consulted on 15 February 2016.

29 Article 7 of the Agreement between the Belgium-Luxembourg Economic Union and the Government of the Republic of Mozambique on the Reciprocal Promotion and Protection of Investment, 18 July 2006, available at http://investmentpolicyhub.unctad.org/ Download/TreatyFile/393, consulted on 15 February 2016.

30 Suez, Sociedad General de Aguas de Barcelona S. A. and Vivendi Universal S. A. v. The Argentine Republic (ICsid Case No. ARB/03/19), Decision on Liability, 30 July 2010, Exhibit CLA-79, para. 188.

31 ElPaso Energy International Company v. The Argentine Republic (ICSID Case No. ARB/03/15), 31 October 2011, paras. 356, 358. 
The granting of a permit is one example of a regulatory power that often involves environmental considerations. In this context, it should be noted that " $[$ t he obligations of the host State towards foreign investors derive from the terms of the applicable investment treaty and not from any set of expectations investors may have or claim to have". ${ }^{32}$

The State's right to regulate in the public interest has gradually emerged in investment arbitration practice. An example is found in the Marvin Feldman v. Mexico ICSID case: "(G)overnment must be free to act in the broader public interest through protection of the environment, new or modified tax regimes, the granting or withdrawal of government subsidies, reductions or increases in tariff levels, imposition of zoning restrictions and the like. Reasonable governmental regulation of this type cannot be achieved if any business that is adversely affected may seek compensation". 33

The same approach is taken in recent model BITs that confer a wider latitude to States, enabling them to determine their own level of environmental protection and place the BIT within the broader network of multilateral environmental treaties. ${ }^{34}$ One example of this is the Southern African Development Community Protocol on Finance and Investment, which reads as follows: "Nothing in this Annex shall be construed as preventing a State Party from exercising its right to regulate in the public interest and to adopt, maintain or enforce any measure that it considers appropriate to ensure that investment activity is undertaken in a manner sensitive to health, safety or environmental concerns". ${ }^{35}$

32 MTD Equity Sdn. Bhd. and MTD Chile S.A. v. Republic of Chile (ICSID Case No. ARB/01/7), Decision on Annulment, 21 March 2007, para. 67.

33 Marvin Feldman v Mexico (ICSID Case No. ARB(AF)/99/1), Award, 16 December 2002, para. 103.

34 Recent agreements add specific language to ensure the protection of the environment and appropriate corporate behavior. For instance, countries sometimes include clauses that confirm their right to establish their own level of environmental protection, that carve out environmental-related clauses from ISDS or that include language aimed at enhancing coherence between IIA and multilateral environmental agreements. J. Zhan, "Investment policies for sustainable development: addressing policy challenges in a new investment landscape," in Roberto Echandi and Pierre Sauvé, eds., Prospects in International Investment Law and Policy (Cambridge University Press, 2013), p. 26. See also UNCTAD, World Investment Report: Investing in a Low-Carbon Economy (UNCTAD/WIR/2010).

35 Article 14 of the Annex 1 "Cooperation on Investment" of the SADC Protocol on Finan- 
The regulatory power of a State can also be framed by way of general exceptions, which include the possibility to adopt environmental measures. Some examples are given below:

\section{BIT China-Canada}

2. Provided that such measures are not applied in an arbitrary or unjustifiable manner, or do not constitute a disguised restriction on international trade or investment, nothing in this Agreement shall be construed to prevent a Contracting Party from adopting or maintaining measures, including environmental measures: a) necessary to ensure compliance with laws and regulations that are not inconsistent with the provisions of this Agreement; b) necessary to protect human, animal or plant life or health; or c) relating to the conservation of living or non-living exhaustible natural resources if such measures are made effective in conjunction with restrictions on domestic production or consumption. ${ }^{36}$

\section{BIT Canada-Slovak Republic}

1. Subject to the requirement that such measures are not applied in a manner that would constitute arbitrary or unjustifiable discrimination between investments or between investors, or a disguised restriction on international trade investment, nothing in this Agreement shall be construed to prevent a Contracting Party from adopting or enforcing measures necessary: (a) to protect human, animal or plant life or health; (b) to ensure compliance with laws and regulations that are not inconsistent with the provisions of this Agreement; or (c) for the conservation of living or non-living exhaustible natural resources. ${ }^{37}$

ce and Investment, 18 August 2006, available at http://www.sadc.int/files/4213/5332/6872/ Protocol_on_Finance_Investment2006.pdf, consulted on 15 February 2016.

36 Article 33 "General Exceptions" of the Agreement Between the Government of Canada and the Government of the People's Republic of China for the Promotion and Reciprocal Protection of Investments, 9 September 2012, http://investmentpolicyhub. unctad.org/IIA/country/42/treaty/778, consulted on 14 February 2016.

37 Article IX of the Agreement between Canada and the Slovak Republic for the Promotion 
While general exceptions for the protection of the environment modeled on GATT Article XX are quite rare, ${ }^{38}$ Canada has on a number of occasions incorporated such provisions into its BITs with OECD states. Moreover, the China-New Zealand Free Trade Agreement incorporates GATT Article XX. Further still, NAFTA's (North American Free Trade Agreement) Article 1114 provides a differently formulated but substantively similar provision: "Nothing in this Chapter shall be construed to prevent a Party from adopting, maintaining or enforcing any measure otherwise consistent with this Chapter that it considers appropriate to ensure that investment activity in its territory is undertaken in a manner sensitive to environmental concerns". ${ }^{39}$

Similarly drafted provisions may be found in the Canada-Romania вІт. ${ }^{40}$ Where environmental exceptions are not inserted, there is a risk that arbitral tribunals will find a violation of a treaty obligation if the State adopts a measure intended to protect the environment. This was the case in Santa Elena v. Costa Rica. ${ }^{41}$ In that case, the Tribunal found that environmental protection measures could still amount to expropriation and that the State continued to be liable to pay compensation: "Expropriatory environmental measures — no matter how laudable and beneficial to society as a whole - are in this respect, similar to any other expropriatory measures that a state may take in order to implement its policies: where property

and the Protection of Investments, 20 July 2010, available at http://investmentpolicyhub. unctad.org/Download/TreatyFile/634, consulted on 15 February 2016.

38 See Newcombe, A. and Paradell, L., Law and Practice of Investment Treaties (Kluwer Law International, 2009), p. 500: "The use of general exceptions clauses modelled on Article XX, GATT, or Article XIV, GATS, is not common in IIAs. Canada is unique amongst Organization for Economic Cooperation and Development (OECD) states in including the exceptions in its BITs". See also, Burke-White, W. and von Staden, A., "Investment Protection in Extraordinary Times: The Interpretation of Non-Precluded Measure Provisions in Bilateral Investment Treaties", 48(2) (2008) Virginia Journal of International Law 307.

39 NAFTA Agreement, Chapter 11, Article 11.10, available at https://ustr.gov/sites/default/files/uploads/agreements/fta/korus/asset_upload_file587_12710.pdf, consulted on 25 February 2016.

40 Article XVII-2, Agreement between the Government of Romania and the Government of Canada for the Promotion and Reciprocal Protection of Investments, 8 May 2009, available at http://investmentpolicyhub.unctad.org/Download/TreatyFile/3503, consulted on 26 February 2016.

${ }^{41}$ Compañia del Desarrollo de Santa Elena, S.A. v. The Republic of Costa Rica (ICSID Case No. ARB/96/1), Final Award, 17 February 2000. 
is expropriated, even for environmental purposes, whether domestic or international, the state's obligation to pay compensation remains". ${ }^{42}$

\section{Corporate Social Responsibility and Other Standards}

A third way in which environmental considerations form part of international investment law are the standards, guidelines and obligations placed upon the investor during the life of the investment. The structure of the international legal order in part explains the recourse to international standards. Traditional channels for the production of rules of international law often fail to accommodate the needs of the diverse range of actors in the international community. Even though international treaties and custom play a fundamental role, they cannot cover the vast sphere of international activity. ${ }^{43}$ This is why soft law, standards, and guidelines perform a role complementary to the application of general principles in international investment law. They are resorted to as vehicles of socialization for promoting values. They also contribute to strengthening the accountability of the actors involved in investment activities.

In this context, the growth of eco-friendly and socially responsible standards applicable to investors allows for possible synergies between environmental and investment protection. Corporate social responsibility (CSR) standards with environmental dimensions can be found in a number of BITs:

\section{BIT Canada-Benin}

Each Contracting Party should encourage enterprises operating within its territory or subject to its jurisdiction to voluntarily incorporate internationally recognized standards of corporate social responsibility in their practices and internal policies, such as statements of principle that have been endorsed or are supported by the Contracting Parties. These principles address issues such as labour, the environment, human rights, community relations and anti-corruption. ${ }^{44}$

\footnotetext{
$42 \quad$ Ibid., para 72.

43 Boisson de Chazournes, L., "Standards and Guidelines: Some Interface with Private Investments" in Tullio Treves, Francesco Seatzu and Seline Trevisanut eds., Foreign Investment, International Law and Common Concerns (Routledge. 2013), p. 103.

44 Article 16 of the Agreement between the Government of Canada and the Government of the Republic of Benin for the Promotion and Reciprocal Protection of Investments,
} 


\section{BIT Brazil-Mozambique}

The investor and investments shall strive to carry out the highest level possible of contributions to the sustainable development of the host State and the local community, by means of the adoption of a high degree of socially responsible practices, taking as a reference the voluntary principles and standards defined in Annex II 'Corporate and Social Responsibility'. ${ }^{45}$

Similarly, CSR standards may be taken into consideration in the interpretation of BIT provisions relating to non-discrimination and serve as a justified basis to grant preferential treatment to investors. This is the case in the free trade agreement between the EU and the Republic of Korea:

The Parties shall strive to facilitate and promote trade and foreign direct investment in environmental goods and services, including environmental technologies, sustainable renewable energy, energy efficient products and services and eco-labelled goods, including through addressing related non-tariff barriers. The Parties shall strive to facilitate and promote trade in goods that contribute to sustainable development, including goods that are the subject of schemes such as fair and ethical trade and those involving corporate social responsibility and accountability. ${ }^{46}$

Other developments involve the requirement for the conduct of an environmental impact assessment. As the International Court of Justice stated in the Pulp Mills on the River Uruguay case:

[T] he obligation to protect and preserve [...] has to be interpreted in accordance with a practice, which in recent years has gained so much

9 January 2013, available at http://investmentpolicyhub.unctad.org/Download/TreatyFile/438, consulted on 16 February 162016.

45 Article 10 of the Acordo de cooperacão e facilitacão de investimentos entre o governo da república federativa do Brasil e o governo da República de Moçambique, 2015, available at: http://investmentpolicyhub.unctad.org/Download/TreatyFile/3352, consulted on 15 February 2016.

46 Article 13.6 (2) of the EU-Korea FTA, 16 September 2010, available at http://investmentpolicyhub.unctad.org/Download/TreatyFile/2602, consulted on 15 February 2016. 
acceptance among States that it may now be considered a requirement under general international law to undertake an environmental impact assessment where there is a risk that the proposed industrial activity may have a significant adverse impact in a transboundary context, in particular, on a shared resource. ${ }^{47}$

The requirement of impact assessment allows the host State to ensure that its environmental standards are taken into account and assess whether the investment positively or negatively complies with them. The scope of an impact assessment can expand to environmental and socio-cultural rights. Article 15 of the 2012 SADC Model BIT highlights the importance of this requirement and provides that:

15.1. Investors and their investments have a duty to respect human rights in the workplace and in the community and State in which they are located. Investors and their investments shall not undertake or cause to be undertaken acts that breach such human rights. Investors and their investments shall not assist in, or be complicit in, the violation of the human rights by others in the Host State, including by public authorities or during civil strife.

15.2. Investors and their investments shall act in accordance with core labour standards as required by the ILO Declaration on Fundamental Principles and Rights of Work, 1998.

15.3. Investors and their investments shall not [establish,] manage or operate Investments in a manner inconsistent with international environmental, labour, and human rights obligations binding on the Host State or the Home State, whichever obligations are higher. ${ }^{48}$

\section{Environmental Protection: On the Use of Procedural Devices}

The procedural devices of international courts and tribunals, including investment tribunals, may also be crucial for ensuring environmental protection. They include, inter alia, the resort to experts, counterclaims and res judicata.

\footnotetext{
47 Pulp Mills on the River Uruguay (Argentina v. Uruguay), ICJ Reports 2010 p. 14, para. 204. 48 SADC Model BIT, 2012, available at http://www.iisd.org/itn/wp-content/ uploads/2012/10/sadc-model-bit-template-final.pdf, consulted on 16 February 2016.
} 


\title{
A. The Resort to Experts
}

In recent years there has been an increasing number of disputes in which experts have played a role in the assessment of environmental or scientific issues that a case may involve. One of the reasons leading to the appointment of experts is the complexity of the notion of environmental harm and of its assessment. In the determination of the range and the scope of alleged environmental harm, tribunals may seek the assistance of experts. The parties might also appoint their own experts to explain the alleged damages.

Recent cases brought before the International Court of Justice have attracted attention due to the significance given to the use of experts. In the Pulp Mills on the River Uruguay case, the Court noted that:

\begin{abstract}
Regarding those experts who appeared before it as counsel at the hearings, the Court would have found it more useful had they been presented by the Parties as expert witnesses under Articles 57 and 64 of the Rules of Court, instead of being included as counsel in their respective delegations. The Court indeed considers that those persons who provide evidence before the Court based on their scientific or technical knowledge and on their personal experience should testify before the Court as experts, witnesses or in some cases in both capacities, rather than counsel, so that they may be submitted to questioning by the other party as well as by the Court. ${ }^{49}$
\end{abstract}

In the Whaling in the Antarctic case, ${ }^{50}$ as well as in the Nicaragua $v$. Costa Rica case, ${ }^{51}$ the parties relied heavily on scientific experts who testified before the Court.

Courts and Tribunals can also appoint experts of their own accord. In their Dissenting Opinion in the Pulp Mills on the River Uruguay case, Judges Simma and Al-Khasawneh noted:

The adjudication of disputes in which the assessment of scientific questions by experts is indispensable ... [and] ... requires an inter-

\footnotetext{
49 Pulp Mills on the River Uruguay (Argentina v. Uruguay), ICJ Reports 2010 p. 14, para. 167.

50 Whaling in the Antarctic (Australia v. Japan), ICJ Reports 2014 p. 226, paras. 74-75.

51 Construction of a Road in Costa Rica along the San Juan River (Nicaragua v. Costa Rica), Judgment, 16 December 2015, paras. 45, 175-176, 194, 204.
} 
weaving of legal process with knowledge and expertise that can only be drawn from experts properly trained to evaluate the increasingly complex nature of the facts put before the Court. The Court on its own is not in a position to adequately assess and weigh complex evidence of the type presented by the Parties.

We consider, however, that the Court had another, more compelling alternative, provided in Article 50 of its Statute: "The Court may, at any time, entrust any individual, body, bureau, commission, or other organization that it may select, with the task of carrying out an enquiry or giving an expert opinion." (Emphasis added) [...] Although, [...] this procedure does not allow for the parties to cross-examine the Courtappointed experts, it nevertheless grants them a voice in assessing the opinions that such experts might produce. The Court is therefore endowed with considerable discretion, and two well-defined procedures under its Statute and Rules, to have recourse to outside sources of expertise in handling complex scientific or technical disputes. ${ }^{52}$

One important question is whether science may be considered a legal or a factual question. ${ }^{53}$ Courts and tribunals must appropriately distinguish between legal and non-legal issues when recourse to expertise is sought. It is important to bear in mind that the role of the expert is to assist the court or tribunal in determining the relevant facts of the dispute. ${ }^{54}$ Certain standards assist in the recourse to experts, such as cross-examination ${ }^{55}$ where the experts are appointed by the parties or the opportunity to respond to the choice of a court-appointed expert and the evidence they give. ${ }^{56}$

Guidance on the recourse to experts can also be sought from the WTO. The WTO's Dispute Settlement Body has developed procedures that aim to ensure the sound administration of justice and transparency when experts are involved in proceedings. Written and oral consultations, meetings, and the opportunity to comment on expert reports are all important mechanisms that are utilized to this end.

52 Pulp Mills on the River Uruguay (Argentina v. Uruguay), ICJ Reports 2010 p 14, paras. 3, 8.

53 Mbengue, M., "The Role of Experts Before the International Court of Justice: The Whaling in the Antarctic Case" (2015) Questions of International Law, Zoom-in 14, 3-12.

54 Ibid., 8.

55 As provided for under Rule 62 of the ICJ Rules.

56 As provided for under Rule 50 of the ICJ Rules. 
A recent investment award highlights the role played by expert opinions and statements. In the Perenco v. Ecuador dispute, ${ }^{57}$ the Respondent through a counterclaim alleged the violation of the applicable BIT by the investor. The State claimed to have suffered three billion dollars in damage due to the massive pollution of the Amazon forest. After analyzing the facts and law around the counterclaim, the Tribunal recognized that there had been some contamination of soils for which the investor was responsible.$^{58}$ However, the Tribunal also noted the difficulty of determining the degree of liability on the basis of expert reports produced by the parties and decided as a result to appoint its own expert. ${ }^{59}$ The transparency of the process was enhanced as the Tribunal allowed the parties' experts to comment on the expert reports admitted as evidence. ${ }^{60}$

\section{B. Counterclaims}

In investment disputes, counterclaims have recently gained more interest from States willing to enforce obligations against the investor or claim compensation for the damages they suffer. To the extent that they meet the requirements of admissibility and are within the tribunal's jurisdiction, counterclaims have the potential to absorb environmental obligations and incorporate them into the resolution of the dispute.

Recently, environmental protection and assessment of environmental harm were key issues of the above-mentioned dispute between Ecuador and Perenco. Following a first decision on the merits, Ecuador used a counterclaim as a procedural device to enforce domestic environmental obligations relating to oil extraction. In a unique decision, the Tribunal focused on the assessment of environmental harm claimed by Ecuador in the Amazon rain forest in its counterclaim.

Before entering into a detailed assessment of the damages suffered by the Respondent State, the Tribunal unequivocally recognized the right for a State to claim environmental harm and the right to be compensated

\footnotetext{
57 Perenco Ecuador Ltd. v. The Republic of Ecuador and Empresa Estatal Petróleos del Ecuador (Petroecuador) (ICSID Case No. ARB/08/6), Interim Decision on the Environmental Counterclaim, 11 August 2015.

58 Ibid., para. 582.

59 Ibid., paras. 587.

60 Ibid., para. 588.
} 
for such harm. As noted, Ecuador had evaluated its environmental damages at three billion U.S. dollars. The Tribunal said:

Ecuador presented the environmental counterclaim on the basis that its experts had determined the existence of an "environmental catastrophe" [...] Ecuador viewed this as an extremely serious matter deserving the most careful consideration by the Tribunal. On this point, the Tribunal cannot but agree. Proper environmental stewardship has assumed great importance in today's world. The Tribunal agrees that if a legal relationship between an investor and the State permits the filing of a claim by the State for environmental damage caused by the investor's activities and such a claim is substantiated, the State is entitled to full reparation in accordance with the requirements of the applicable law. ${ }^{61}$

In resolving the dispute, the Tribunal applied Ecuadorian law as well as international law, noting that the Rio Declaration inspired the drafting of Ecuadorian legal provisions relating to environmental protection. ${ }^{62} \mathrm{It}$ is interesting to highlight that, instead of focusing on the investor's economic benefits recognized by treaties, the Tribunal analyzed the State's rights, including non-economic "imperatives of the protection of the environment", recognizing that:

[A] State has wide latitude under international law to prescribe and adjust its environmental laws, standards and policies in response to changing views and a deeper understanding of the risks posed by various activities, including those of extractive industries such as oilfields. All of this is beyond any serious dispute and the Tribunal enters into this phase of the proceeding mindful of the fundamental imperatives of the protection of the environment in Ecuador. ${ }^{63}$

Basing its reasoning on environmental protection, the Tribunal held the investor liable for the environmental harm that occurred in the Amazon rainforest in connection with the investor's oil extraction activities. ${ }^{64}$

\footnotetext{
61 Ibid., paras. 34.

62 Ibid., para. 331.

63 Ibid., para. 35.

64 Ibid., para. 582.
} 
As seen, the filing of a counterclaim on a violation of Ecuadorian environmental law was an opportunity for an investment tribunal to analyze the investors' conduct against the State's non-economic rights that include the right to protect its environment.

\section{Res Judicata and Environmental Issues}

Res judicata is a widely recognized principle of law which operates to bar proceedings involving a matter that has already been decided upon, and it can be applied in most formal dispute settlement fora when the parties to a dispute and the facts therein are the same as in a previous dispute. ${ }^{65}$ This said, it is important to bear in mind that certain decisions rendered in environmental disputes may result in detrimental outcomes after a judgment has been given. Very interestingly, the Tribunal in the Indus Waters Kishenganga Arbitration took this into account when it said the following:

In its Partial Award, the Court stated that "stability and predictability in the availability of the waters of the Kishenganga/Neelum for each Party's use are vitally important for the effective utilization of rights accorded to each Party by the Treaty (including its incorporation of customary international environmental law)". This remains true. Indeed, the Court rejected a fully ambulatory interpretation of Paragraph 15(iii) of the Treaty for this reason. At the same time, the Court considers it important not to permit the doctrine of res judicata to extend the life of this Award into circumstances in which its reasoning no longer accords with reality along the Kishenganga/Neelum. The minimum flow will therefore be open to reconsideration as laid down in the following paragraph.

The KHEP should be completed in such a fashion as to accommodate possible future variations in the minimum flow requirement. If, beginning seven years after the diversion of the Kishenganga/Neelum through the KHEP, either Party considers that reconsideration of the Court's determination of the minimum flow is necessary, it will be

65 Shigeta, Y., International Judicial Control of Environmental Protection: Standard Setting, Compliance Control and the Development of International Environmental Law by the International Judiciary (Kluwer Law International, 2010), p. 193. 
entitled to seek such reconsideration through the Permanent Indus Commission and the mechanisms of the Treaty. ${ }^{66}$

This award is unique in the way that it takes into account the potentially long term detrimental effects of a project on the environment while identifying a means for addressing these potential impacts. Additionally, it indicates a venue for dealing with this issue. Last but not least, it was bold enough to go beyond the res judicata principle.

Environmental concerns have increasingly been considered in the international legal order. Through a variety of means, including by explicit provisions and interpretation, these concerns have also made their way into international investment law. Insights drawn from the practice of international courts and tribunals may strengthen the approaches taken in investment disputes.

\section{References}

\section{Books}

Newcombe, A. \& Paradell, L., Law and Practice of Investment Treaties, (Kluwer Law International, 2009).

Shigeta, Y., International Judicial Control of Environmental Protection: Standard Setting, Compliance Control and the Development of International Environmental Law by the International Judiciary, (Kluwer Law International, 2010).

\section{Articles}

Boisson de Chazournes, L., "Rules of Interpretation and Investment Arbitration”, in Meg Kinnear et al., eds., Building International Investment Law: The First 50 Years of ICSID, (Kluwer Law International, 2015).

Boisson de Chazournes, L., "Standards and Guidelines: Some Interface with Private Investments", in Tullio Treves, Francesco Seatzu and Seline Trevisanut eds., Foreign Investment, International Law and Common Concerns, Routledge, 2013.

66 Indus Waters Kishenganga Arbitration (Pakistan v. India), Partial Award (PCA 2013), paras. 118-119. 
Boyle, A., "Gabčíkovo-Nagymaros Case: New Law in Old Bottles", Yearbook of International Environmental Law 8, 1997, 13-20.

Burke White, W. \& von Staden, A., "Investment Protection in Extraordinary Times: The Interpretation of Non-Precluded Measure Provisions in Bilateral Investment Treaties", Virginia Journal of International Law, 2008, 48 (2), 307.

Mbengue, M., "The Role of Experts Before the International Court of Justice: The Whaling in the Antarctic Case", Questions of International Law: Zoom-In 14, 2015, 3-12.

Zhan, J., "Investment policies for sustainable development: addressing policy challenges in a new investment landscape", in Roberto Echandi and Pierre Sauvé eds., Prospects in International Investment Law and Policy, Cambridge University Press, 2013.

\section{Jurisprudence}

Award in the Arbitration Regarding the Iron Rhine Railway (Kingdom of Belgium/Kingdom of the Netherlands), Award, 24 May 2005, Report of International Arbitral Awards, Vol. XXVII, pp. 35-125.

Case Concerning Pulp Mills on the River Uruguay (Argentina v. Uruguay), ICJ Reports 2010.

Case Concerning the Gabčíkovo-Nagymaros Project (Hungary/Slovakia), ICJ Reports 1997.

Compañía del Desarrollo de Santa Elena, S.A. v. The Republic of Costa Rica (ICSID Case No. ARB/96/1), Final Award, 17 February 2000.

Construction of a Road in Costa Rica along the San Juan River (Nicaragua

v. Costa Rica), Judgment, 16 December 2015.

El Paso Energy International Company v. The Argentine Republic (ICSID Case No. ARB/03/15), 31 October 2011.

Indus Waters Kishenganga Arbitration (Pakistan v. India), Partial Award (PCA 2013).

Legality of the Threat or Use of Nuclear Weapons, Advisory Opinion, ICJ Reports 1996.

Marvin Feldman v Mexico (ICSID Case No. ARB(AF)/99/1), Award, 16 December 2002.

MTD Equity Sdn. Bhd. and MTD Chile S.A. v. Republic of Chile (ICSID Case No. ARB/01/7), Decision on Annulment, 21 March 2007.

Perenco Ecuador Ltd. v. The Republic of Ecuador and Empresa Estatal Petróleos del Ecuador (Petroecuador) (ICSID Case No. ARB/08/6), 
Interim Decision on the Environmental Counterclaim, 11 August 2015.

Pulp Mills on the River Uruguay (Argentina v. Uruguay), ICJ Reports 2010. Suez, Sociedad General de Aguas de Barcelona S.A. and Vivendi Universal S.A. v. The Argentine Republic (ICSID Case No. ARB/03/19), Decision on Liability, 30 July 2010, Exhibit CLA-79.

United States - Import Prohibition of Certain Shrimp and Shrimp Products WT/DS58/AB/R (1998).

United States - Measures Concerning the Importation, Marketing and Sale of Tuna and Tuna Products, WT/DS381/AB (2012).

United States - Standards for Reformulated and Conventional Gasoline, WT/DS2 (1996).

Whaling in the Antarctic (Australia v. Japan), ICJ Report, 2014.

\section{Documents/Bilateral Investment Treaties}

Acordo de cooperacão e facilitacão de investimentos entre o governo da república federativa do Brasil e o governo da república de Moçambique, 2015, available at: http:/ /investmentpolicyhub.unctad.org/ Download/TreatyFile/3352, consulted on 15 February 2016.

Agreement between Canada and the Slovak Republic for the Promotion and the Protection of Investments, 20 July 2010, available at http:/ / investmentpolicyhub.unctad.org/Download/TreatyFile/634, consulted on 15 February 2016.

Agreement between the Belgium-Luxembourg Economic Union and the Government of the Republic of Mozambique on the Reciprocal Promotion and Protection of Investment, 18 July 2006, available at http://investmentpolicyhub.unctad.org/Download/TreatyFile/393, consulted on 15 February 2016.

Agreement Between the Government of Canada and the Government of the Republic of Benin for the Promotion and Reciprocal Protection of Investments, 9 January 2013, available at: http:/ / investmentpolicyhub.unctad.org/IIA/country/35/treaty/563, consulted on 14 February 2016.

Agreement between the Government of Canada and the Government of the People's Republic of China for the Promotion and Reciprocal Protection of Investments, 9 September 2012, http: / investmentpolicyhub.unctad.org/IIA/country/42/treaty/778, consulted on 14 February 2016. 
Agreement Between the Government of Canada and the Government of the People's Republic of China for the Promotion and Reciprocal Protection of Investments, 9 September 2012, http://investmentpolicyhub.unctad.org/IIA/country/42/treaty/778, consulted on 14 February 2016.

Agreement between the Government of Canada and the Government of the Republic of Benin for the Promotion and Reciprocal Protection of Investments, 9 January 2013, available at http:/ /investmentpolicyhub.unctad.org/Download/TreatyFile/438, consulted on 16 February 162016.

Agreement between the Government of Romania and the Government of Canada for the Promotion and Reciprocal Protection of Investments, 8 May 2009, available at http:/ investmentpolicyhub.unctad. org/Download/TreatyFile/3503, consulted on 26 February 2016.

Annex 1 "Cooperation on Investment" of the SADC Protocol on Finance and Investment, 18 August 2006, available at http:/ /www.sadc.int/ files/4213/5332/6872/Protocol_on_Finance_Investment2006. pdf, consulted on 15 February 2016.

EU-Korea FTA, 16 September 2010, available at http://investmentpolicyhub.unctad.org/Download/TreatyFile/2602, consulted on 15 February 2016.

NAFTA Agreement, Chapter 11, Article 11.10, available at https://ustr.gov/ sites/default/files/uploads/agreements/fta/korus/asset_upload_file587_12710.pdf, consulted on 25 February 2016.

Protocol of the Agreement between the Swiss Confederation and the United Mexican States on the Promotion and Reciprocal Protection of Investments, 10 July 1995, available at http://investmentpolicyhub.unctad.org/Download/TreatyFile/2006, consulted on 15 February 2016.

SADC Model BIT, 2012, available at http:/ /www.iisd.org/itn/wp-content/ uploads/2012/10/sadc-model-bit-template-final.pdf, consulted on 16 February 2016.

Treaty between the Government of the United States of America and the Government of the Republic of Rwanda Concerning the Encouragement and Reciprocal Protection of Investment, 19 February 2008, available at: http://go.usa.gov/3pmXd, consulted on 14 February 2016.

UNCTAD Investment Policy Framework for Sustainable Development, Principles for Investment Policy Making (2015), available at http:// 
unctad.org/en/PublicationsLibrary/diaepcb2015d5_en.pdf, consulted on 15 February 2016

UNCTAD World Investment Report: Investing in a Low-Carbon Economy (UNCTAD/WIR/2010). 
